\title{
The susceptibility of the giant freshwater prawn Macrobrachium rosenbergii to Lactococcus garvieae and its resistance under copper sulfate stress
}

\author{
Winton Cheng ${ }^{1, *}$, Ching-Hsien Wang ${ }^{2}$ \\ ${ }^{1}$ Department of Aquaculture, and ${ }^{2}$ Institute of Tropical Agriculture, National Pingtung University of Science and Technology, \\ Pingtung, Taiwan, 912, Republic of China
}

\begin{abstract}
Addition of copper sulfate (0.1 to $\left.0.4 \mathrm{mg} \mathrm{l}^{-1}\right)$ to tryptic soy broth (TSB) had no effect on growth rate of the bacterial pathogen Lactococcus garvieae. Giant freshwater prawns Macrobrachium rosenbergii were injected with $L$. garvieae $\left(4 \times 10^{6}\right.$ colony-forming units [cfu] prawn $\left.{ }^{-1}\right)$ grown in TSB or TSB containing copper sulfate at $0.1,0.2,0.3$ or $0.4 \mathrm{mg} \mathrm{l}^{-1}$. After $48 \mathrm{~h}$, the cumulative mortality was significantly $\left(\mathrm{p}<0.05\right.$ ) higher for prawns exposed to $L$. garvieae grown in $0.4 \mathrm{mg} \mathrm{l}^{-1}$ copper sulfate than at the lower concentrations examined. In other experiments, prawns were injected with TSB-grown L. garvieae $\left(4 \times 10^{6}\right.$ and $\left.2 \times 10^{5} \mathrm{cfu} \mathrm{prawn}^{-1}\right)$, then held in water containing copper sulfate. After $8 \mathrm{~h}$ the mortality of $L$. garvieae-exposed prawns held in water containing $0.4 \mathrm{mg}$ $\mathrm{l}^{-1}$ copper sulfate was significantly higher than prawns held in water containing 0.2 and $0.3 \mathrm{mg} \mathrm{l}^{-1}$ copper sulfate. At the lower L. garvieae density, cumulative mortality of prawns increased directly with ambient copper sulfate concentrations in the range of 0.2 to $0.4 \mathrm{mg} \mathrm{l}^{-1}$. All prawns survived a $168 \mathrm{~h}$ exposure to $0.1 \mathrm{mg} \mathrm{l}^{-1}$ copper sulfate. Prawns exposed to different concentrations of copper sulfate were examined for hemocyte density, phenoloxidase activity and respiratory burst. No significant differences in hemocyte density were observed among treatments. In prawns following a $48 \mathrm{~h}$ exposure to $0.1 \mathrm{mg} \mathrm{l}^{-1}$ copper sulfate, phenoloxidase activity was decreased, but respiratory burst was increased. In conclusion, copper sulfate increased the virulence of L. garvieae to M. rosenbergii and modulated its immune system. Copper sulfate at $0.1 \mathrm{mg} \mathrm{l}^{-1}$ decreased susceptibility of M. rosenbergii to $L$ garvieae infection, whereas at $0.2 \mathrm{mg} \mathrm{l}^{-1}$ the susceptibility was increased. The generation of superoxide anion by $M$. rosenbergii exposed to copper sulfate at a concentration higher than $0.2 \mathrm{mg} \mathrm{l}^{-1}$ was considered to be cytoxic.
\end{abstract}

KEY WORDS: Macrobrachium rosenbergii - Lactococcus garvieae - Copper sulfate - Hemocyte count · Challenge test $\cdot$ Phenoloxidase activity $\cdot$ Respiratory burst

\section{INTRODUCTION}

The giant freshwater prawn Macrobrachium rosenbergii is commercially important in Taiwan as well as the world as a primary inland cultured species (New 1995). Disease outbreaks caused by yeast infections in the cool season and Enterococcus-like infections in the hot season resulted in declined production of farmed

*E-mail: winton@mail.npust.edu.tw prawns in Taiwan (Cheng \& Chen 1998a,b). Recently, this causative bacterium has been identified as Lactococcus garvieae by polymerase chain reaction assay and 16s rDNA sequencing (Chen et al. 2001).

Hemocytes are involved in phagocytosis by eliminating microbes or foreign particles (Hose et al. 1990, Bachère et al. 1995). In decapoda crustaceans, 3 types of circulating hemocytes are commonly recognized: hyaline, semi-granular and granular cells (Tsing et al. 1989). Environmental contaminants have been reported to cause a reduction in hemocyte numbers in 
the common shrimp Crangon crangon (Smith \& Johnston 1992) and shore crab Carcinus maenas (Truscott \& White 1990, Victor et al. 1990, Le Moullac \& Haffner 2000). Cheng \& Chen (2000) reported from tests on exposure of Macrobrachium rosenbergii to different $\mathrm{pH}$ and temperatures that both total hemocyte count (THC) and penoloxidase activity were minimal at $\mathrm{pH} 9.0$ to 9.5 and 33 to $34^{\circ} \mathrm{C}$. This supports the observation of Cheng \& Chen (1998b) that $M$. rosenbergii is vulnerable to Lactococcus garvieae under these environmental conditions.

Hemocytes are involved not only in coagulation but also in the production of melanin by the prophenoloxidase system (Johansson \& Söderhäll 1989, Söderhäll et al. 1996). The prophenoloxidase system, which is contained in the granular cells, is activated by the prophenoloxidase activating enzyme, a serine protease that is in turn activated by microbial cell components such as $\beta$-1,3-glucan or lipopolysaccharides from fungal cell walls (Söderhäll 1983, Smith et al. 1984). The activity of the phenoloxidase system has been reported for brown shrimp Penaeus californiensis (Herãndez-López et al. 1996), and Macrobrachium rosenbergii (Cheng \& Chen 2000). Environmental contaminants have been reported to cause a reduction of phenoloxidase activity of Crangon crangon and Carcinus maenas (Truscott \& White 1990, Smith \& Johnston 1992, Smith et al. 1995).

The mechanism involved in phagocytosis encompasses the generation of various reactive oxygen intermediates and has been observed in several species of decapod crustaceans (Bell \& Smith 1993, Song \& Hsieh 1994, Le Moullac et al. 1998). Once the pathogen infects the host, it activates the host's NADPH-oxidase, which in turn produces several reactive oxygen intermediates such as superoxide anion $\left(\mathrm{O}_{2}^{-}\right)$, hydrogen peroxide $\left(\mathrm{H}_{2} \mathrm{O}_{2}\right)$ and hydroxyl radical $(\mathrm{OH})$ (Homblad \& Söderhäll 1999). These compounds can be directly toxic to pathogens (Roch 1999). This phenomenon, known as respiratory burst, plays an important role in microbicidal activity (Song \& Hsieh 1994).

Copper sulfate is commonly applied in prawn ponds to eradicate filamentous algae. The application of copper sulfate is also very effective in reducing the abundance of phytoplankton including Microcystis and other blue-green algae. The application rate of copper sulfate varies from 0.025 to $2 \mathrm{mg} \mathrm{l}^{-1}$ (Boyd 1990). Since prawn farmers often apply excess amounts of copper sulfate in pond management, the concentrations of copper sulfate remaining in water and their effect on the resistance of cultured prawns are of primary concern.

The 24 and $96 \mathrm{~h}$ median lethal concentration of copper on Macrobrachium rosenbergii postlarvae has been reported to be 1.15 and $0.32 \mathrm{mg} \mathrm{l}^{-1}$, respectively (Ismail et al. 1990). Copper has been reported to affect hemocyte number and induce immunomodulation in bivalves (Suresh \& Mohandads 1990, Pipe et al. 1999). Little is known, however, of the effect of copper on the resistance of decapod crustaceans (Truscott \& White 1990). This study is aimed at determining (1) the growth of Lactococcus garvieae in tryptic soy broth (TSB), (2) the virulence of $L$. garvieae to M. rosenbergii, (3) the resistance of $M$. rosenbergii to $L$. garvieae and (4) the immune parameters of M. rosenbergii under stress from copper sulfate. Hemocyte counts (THC and differential hemocyte counts [DHC]), phenoloxidase activity and respiratory burst (production of superoxide anion) were used as indicators.

\section{MATERIALS AND METHODS}

Effect of copper sulfate on the growth of Lactococcus garvieae. The bacterium L. garvieae isolated from diseased Macrobrachium rosenbergii was used in this study. Previously it had been shown to cause opaque and whitish musculature in experimental infections (Cheng \& Chen 1998a). The bacterium was cultured on tryptic soy agar (Difco) for $24 \mathrm{~h}$ at $28^{\circ} \mathrm{C}$ before being transferred to $10 \mathrm{ml}$ TSB (Difco) for $24 \mathrm{~h}$ at $30^{\circ} \mathrm{C}$ as a stock bacterial broth for growth tests. Inoculum for the growth tests consisted of $0.5 \mathrm{ml}$ of this stock broth culture.

The concentration of copper sulfate was prepared by dissolving $1 \mathrm{~g}$ of anhydrous copper sulfate (Merck reagent grade) in $1 \mathrm{l}$ of distilled water to make $1000 \mathrm{mg}$ $\mathrm{l}^{-1}$ of stock solution. Bacteria were incubated in $50 \mathrm{ml}$ TSB with different concentrations of copper sulfate (control, 0.1, 0.2, 0.3 and $0.4 \mathrm{mg} \mathrm{l}^{-1}$ ) in $250 \mathrm{ml}$ flasks at $30^{\circ} \mathrm{C}$. Each test was conducted in triplicates and bacterial growth was monitored at 12, 24, 48 and $120 \mathrm{~h}$ incubation by measuring the optical density (OD) at $601 \mathrm{~nm}$ using a Model U-2000 spectrophotometer (Hitachi, Tokyo, Japan).

Effect of copper sulfate on the virulence of Lactococcus garvieae. Bacteria from the TSB media containing different concentrations of copper sulfate $(0,0.1$, $0.2,0.3$ and $0.4 \mathrm{mg} \mathrm{l}^{-1}$ ) were tested for the effect of copper sulfate on the virulence of $L$. garvieae. After $24 \mathrm{~h}$ of cultivation, $L$. garvieae in each test medium were harvested by centrifugation at $7155 \times g$ for $15 \mathrm{~min}$ at $4{ }^{\circ} \mathrm{C}$. The pellet was re-suspended in saline solution $(0.85 \%$ $\mathrm{NaCl}$ ) at $2 \times 10^{8}$ colony-forming units (cfu) $\mathrm{ml}^{-1}$ as the stock bacterial suspension for injection.

Macrobrachium rosenbergii (9 to $13 \mathrm{~g}$ in the intermolt stage) were obtained from a commercial farm in Pingtung, Taiwan, and acclimated in the laboratory for 2 wk before experimentation. Twenty microliters of bacterial suspension was then injected into the ventral sinus of the cephalothorax of each prawn. Challenge 
tests were conducted in triplicate using a dose of $4 \times$ $10^{6} \mathrm{cfu}_{\text {prawn }}{ }^{-1}$ following the method of Cheng \& Chen (1998b). The test and control groups comprised 10 prawns each. After injection, each group of 10 prawns was kept in a separate $60 \mathrm{l}$ glass aquarium containing 401 of aerated water. They were fed twice daily with a formulated prawn diet (Shinta Feed Company, Pingtung, Taiwan) and observed for $168 \mathrm{~h}$. During the experiment, water temperature was maintained at $28 \pm$ $1^{\circ} \mathrm{C}$, pH 7.3 to 7.8 , and total hardness $100 \mathrm{mg} \mathrm{l}^{-1}$. Control prawns were injected with an equal volume of sterile saline solution (Table 1).

Effect of copper sulfate on the resistance of Macrobrachium rosenbergii to Lactococcus garvieae. The bacteria were cultured in TSB for $24 \mathrm{~h}$ at $30^{\circ} \mathrm{C}$, then centrifuged at $7155 \times g$ for $15 \mathrm{~min}$ at $4^{\circ} \mathrm{C}$. The supernatant fluid was removed and the bacterial pellet was re-suspended in saline solution $(0.85 \% \mathrm{NaCl})$ at $2 \times 10^{8}$ $\mathrm{cfu} \mathrm{ml}^{-1}$ as the stock bacterial suspension for injection challenges.

Macrobrachium rosenbergii were injected, held, fed and observed as described above. Challenge tests at 2 doses $\left(4 \times 10^{6}\right.$ and $\left.2 \times 10^{5} \mathrm{cfu} \mathrm{prawn}^{-1}\right)$ were conducted in triplicates comprising 10 prawns for each replicate. After injection, prawns were kept in 601 glass aquaria (10 prawns each) containing $40 \mathrm{l}$ of water with different concentrations of copper sulfate $(0,0.1,0.2,0.3$ and $0.4 \mathrm{mg} \mathrm{l}^{-1}$ ). These test solutions were renewed daily. Prawns injected with an equal volume of sterile saline solution and kept in water containing $0.4 \mathrm{mg} \mathrm{l}^{-1}$ copper sulfate served as the unchallenged controls (Table 2).

Effect of copper sulfate on the immune parameters of Macrobrachium rosenbergii. $M$. rosenbergii (20 to $28 \mathrm{~g}$ in the intermolt stage) were obtained and acclimated as described above. Two prawns were kept in each $60 \mathrm{l}$ glass aquarium containing $40 \mathrm{l}$ of test solution at different concentrations of copper sulfate $(0,0.1,0.2$, 0.3 and $0.4 \mathrm{mg} \mathrm{l}^{-1}$ ). The test solutions were renewed daily, and the experiment lasted for $96 \mathrm{~h}$. Each test solution was conducted in triplicates. The prawns were fed as described above.
Hemolymph was sampled at the beginning of the test, at $48 \mathrm{~h}$ and at $96 \mathrm{~h}$. Hemolymph (100 $\mu \mathrm{l})$ was withdrawn from the ventral sinus of each prawn into a $1 \mathrm{ml}$ syringe (25 gauge) containing $0.9 \mathrm{ml}$ anticoagulant solution (trisodium citrate $0.114 \mathrm{M}$, sodium chloride 0.1 M, pH 7.45, osmolality 490 mOsm $\mathrm{kg}^{-1}$ ). A drop of hemolymph was placed on a hemocytometer, and THC and DHC were measured using an inverted phase contrast microscope (Leica DMIL, Leica Microsystems Wetzlar GmbH, Germany).

Phenoloxidase activity was measured spectrophotometrically by recording the formation of dopachrome produced from L-dihydroxyphenylalanine (L-DOPA) (Hernãndez-López et al. 1996). The diluted hemolymph was centrifuged at $300 \times g$ at $4^{\circ} \mathrm{C}$ for $10 \mathrm{~min}$, the supernatant fluid was discarded and the pellet was rinsed, resuspended gently in $1 \mathrm{ml}$ cacodylate-citrate buffer (sodium cacodylate $0.01 \mathrm{M}$, sodium chloride $0.45 \mathrm{M}$, trisodium citrate $0.10 \mathrm{M}, \mathrm{pH} 7.0$ ) and then centrifuged again. The pellet was then resuspended with $200 \mu \mathrm{l}$ cacodylate buffer (sodium cacodylate $0.01 \mathrm{M}$, sodium chloride $0.45 \mathrm{M}$, calcium chloride $0.01 \mathrm{M}$, magnesium chloride $0.26 \mathrm{M}, \mathrm{pH}$ 7.0). One hundred microliters of the cell suspension was incubated with $50 \mu$ l of trypsin $\left(1 \mathrm{mg} \mathrm{ml}^{-1}\right)$, which served as an elicitor, for $10 \mathrm{~min}$ at 25 to $26^{\circ} \mathrm{C}$. Fifty microliters of L-DOPA was added, followed by $800 \mu$ l of cacodylate buffer added 5 min later. The OD at $490 \mathrm{~nm}$ was measured using a Hitachi U-2000 spectrophotometer. The control solution, which consisted of $100 \mu \mathrm{l}$ of cell suspension, $50 \mu \mathrm{l}$ of cacodylate buffer (to replace the trypsin) and $50 \mu \mathrm{l}$ of L-DOPA, was used to measure the background phenoloxidase activity in all test solutions. The background phenoloxidase activity OD values were subtracted from the phenoloxidase activity OD values of prawns for all test conditions and ranged from 0.02 to 0.08 .

Respiratory burst activity of hemocytes was quantified using the reduction of nitroblue tetrazolium (NBT) to formazan as a measure of superoxide anion production (Song \& Hsieh 1994). One hundred microliters of hemolymph in anticoagulant solution was deposited in

Table 1. Susceptibility of Macrobrachium rosenbergii to Lactococcus garvieae incubated in tryptic soy broth with different $\mathrm{CuSO}_{4}$ concentrations at $28 \pm 1^{\circ} \mathrm{C}$, pH 7.3 to 7.8 and total hardness $100 \mathrm{mg} \mathrm{l}^{-1}$. Data in the same column with different letters are significantly different $(p<0.05)$ among the treatments. Values are means \pm SE. cfu: colony-forming units

\begin{tabular}{|c|c|c|c|c|c|c|c|}
\hline \multirow{2}{*}{$\begin{array}{l}\text { Bacteria } \\
\left(\text { cfu prawn }^{-1}\right)\end{array}$} & \multirow{2}{*}{$\begin{array}{c}\text { Ambient } \mathrm{CuSO}_{4} \\
\left(\mathrm{mg} \mathrm{l}^{-1}\right)\end{array}$} & \multirow{2}{*}{$\begin{array}{c}\text { No. } \\
\text { prawns }\end{array}$} & \multicolumn{5}{|c|}{ Cumulative mortality (\%) } \\
\hline & & & 16 & 24 & 48 & 72 & 96 \\
\hline Control & Saline & 30 & 0 & 0 & 0 & 0 & 0 \\
\hline $4 \times 10^{6}$ & 0 & 30 & $13.3 \pm 3.3^{\mathrm{a}}$ & $26.7 \pm 8.8^{\mathrm{a}}$ & $36.7 \pm 3.3^{b}$ & $36.7 \pm 3.3^{b}$ & $36.7 \pm 3.3^{\mathrm{b}}$ \\
\hline $4 \times 10^{6}$ & 0.1 & 30 & $6.7 \pm 3.3^{\mathrm{a}}$ & $20.0 \pm 10.0^{\mathrm{a}}$ & $30.0 \pm 5.8^{\mathrm{b}}$ & $30.0 \pm 5.8^{\mathrm{b}}$ & $30.0 \pm 5.8^{\mathrm{b}}$ \\
\hline $4 \times 10^{6}$ & 0.2 & 30 & $13.3 \pm 6.7^{a}$ & $26.7 \pm 8.8^{\mathrm{a}}$ & $33.3 \pm 6.7^{\mathrm{b}}$ & $36.7 \pm 3.3^{b}$ & $40.0 \pm 5.8^{\mathrm{b}}$ \\
\hline $4 \times 10^{6}$ & 0.3 & 30 & $6.7 \pm 3.3^{\mathrm{a}}$ & $20.0 \pm 0.0^{\mathrm{a}}$ & $33.3 \pm 8.8^{\mathrm{b}}$ & $33.3 \pm 8.8^{\mathrm{b}}$ & $33.3 \pm 8.8^{\mathrm{b}}$ \\
\hline $4 \times 10^{6}$ & 0.4 & 30 & $13.3 \pm 6.7^{a}$ & $40.0 \pm 11.6^{a}$ & $60.0 \pm 6.7^{a}$ & $63.3 \pm 6.7^{a}$ & $66.7 \pm 3.3^{\circ}$ \\
\hline
\end{tabular}


Table 2. Susceptibility of Macrobrachium rosenbergii to Lactococcus garvieae at different $\mathrm{CuSO}_{4}$ concentrations and at $28 \pm 1{ }^{\circ} \mathrm{C}$, pH 7.3 to 7.8 and total hardness $100 \mathrm{mg} \mathrm{l}^{-1}$. Data in the same column with different letters are significantly different (p $\left.<0.05\right)$ among treatments. Values are means \pm SE

\begin{tabular}{|c|c|c|c|c|c|c|c|c|}
\hline \multirow{2}{*}{$\begin{array}{l}\text { Bacteria } \\
\left(\text { cfu prawn }^{-1}\right)\end{array}$} & \multirow{2}{*}{$\begin{array}{c}\text { Ambient } \\
\mathrm{CuSO}_{4}\left(\mathrm{mg} \mathrm{l}^{-1}\right)\end{array}$} & \multirow{2}{*}{$\begin{array}{c}\text { No. } \\
\text { prawns }\end{array}$} & \multicolumn{6}{|c|}{ Cumulative mortality (\%) } \\
\hline & & & 8 & 16 & 24 & 48 & 72 & 96 \\
\hline Control & 0.4 & 30 & 0 & 0 & 0 & 0 & 0 & 0 \\
\hline $4 \times 10^{6}$ & 0 & 30 & $0^{\mathrm{b}}$ & $0^{\mathrm{b}}$ & $6.7 \pm 3.3^{b}$ & $20.3 \pm 0.0^{\mathrm{b}}$ & $23.3 \pm 3.3^{\mathrm{b}}$ & $26.7 \pm 3.3^{\mathrm{bc}}$ \\
\hline $4 \times 10^{6}$ & 0.1 & 30 & $0^{\mathrm{b}}$ & $0^{\mathrm{b}}$ & $3.3 \pm 3.3^{\mathrm{b}}$ & $13.3 \pm 6.7^{b}$ & $16.7 \pm 3.3^{b}$ & $20.0 \pm 0.0^{c}$ \\
\hline $4 \times 10^{6}$ & 0.2 & 30 & $3.3 \pm 3.3^{b}$ & $10.0 \pm 0.0^{\mathrm{b}}$ & $20.0 \pm 5.8^{b}$ & $30.0 \pm 5.8^{\mathrm{ab}}$ & $30.0 \pm 5.8^{\mathrm{ab}}$ & $36.7 \pm 3.3^{b}$ \\
\hline $4 \times 10^{6}$ & 0.3 & 30 & $3.3 \pm 3.3^{b}$ & $10.0 \pm 5.8^{b}$ & $16.7 \pm 3.3^{b}$ & $26.7 \pm 3.3^{\mathrm{b}}$ & $26.7 \pm 3.3^{b}$ & $30.0 \pm 0.0^{\mathrm{bc}}$ \\
\hline $4 \times 10^{6}$ & 0.4 & 30 & $16.7 \pm 6.7^{a}$ & $33.3 \pm 8.8^{\mathrm{a}}$ & $40.0 \pm 10.0^{\mathrm{a}}$ & $46.7 \pm 8.8^{\mathrm{a}}$ & $46.7 \pm 8.8^{\mathrm{a}}$ & $50.0 \pm 5.8^{\mathrm{a}}$ \\
\hline Control & 0.4 & 30 & 0 & 0 & 0 & 0 & 0 & 0 \\
\hline $2 \times 10^{5}$ & 0 & 30 & $0^{\mathrm{a}}$ & $0^{\mathrm{a}}$ & $0^{\mathrm{b}}$ & $0^{\mathrm{c}}$ & $3.3 \pm 3.3^{\mathrm{d}}$ & $3.3 \pm 3.3^{\mathrm{d}}$ \\
\hline $2 \times 10^{5}$ & 0.1 & 30 & $0^{\mathrm{a}}$ & $0^{\mathrm{a}}$ & $0^{\mathrm{b}}$ & $0^{\mathrm{c}}$ & $0^{\mathrm{d}}$ & $0^{\mathrm{d}}$ \\
\hline $2 \times 10^{5}$ & 0.2 & 30 & $0^{\mathrm{a}}$ & $0^{\mathrm{a}}$ & $0^{\mathrm{b}}$ & $0^{\mathrm{c}}$ & $10.0 \pm 0.0^{\mathrm{c}}$ & $10.0 \pm 0.0^{\mathrm{c}}$ \\
\hline $2 \times 10^{5}$ & 0.3 & 30 & $0^{\mathrm{a}}$ & $3.3 \pm 3.3^{\mathrm{a}}$ & $6.7 \pm 3.3^{b}$ & $16.7 \pm 3.3^{b}$ & $23.3 \pm 3.3^{b}$ & $23.3 \pm 3.3^{b}$ \\
\hline $2 \times 10^{5}$ & 0.4 & 30 & $3.3 \pm 3.3^{\mathrm{a}}$ & $10 \pm 5.8^{\mathrm{a}}$ & $16.7 \pm 3.3^{\mathrm{a}}$ & $36.7 \pm 3.3^{\mathrm{a}}$ & $40.0 \pm 0.0^{\mathrm{a}}$ & $40.0 \pm 0.0^{\mathrm{a}}$ \\
\hline
\end{tabular}

microplates previously coated with $100 \mu \mathrm{l}$ of poly-Llysine solution $(0.2 \%)$ to improve cell adhesion. Microplates were centrifuged at $300 \times g$ for $15 \mathrm{~min}$. Plasma was removed and $100 \mu \mathrm{l}$ of zymosan $(0.1 \%$ in Hanks' solution minus phenol red) was added and allowed to react for $30 \mathrm{~min}$ at room temperature. Zymosan was discarded and the hemocytes were washed 3 times with $100 \mu$ l of Hanks' solution, then stained with $100 \mu \mathrm{l}$ of NBT solution $(0.3 \%)$ for $30 \mathrm{~min}$ at room temperature. The NBT solution was removed and the hemocytes were fixed and washed 3 times with $100 \mu \mathrm{l}$ of $70 \%$ methanol and air-dried. Formazan was dissolved by the addition of $120 \mu \mathrm{l}$ of $\mathrm{KOH}$ and $140 \mu \mathrm{l}$ of dimethyl sulfoxide. The OD at $630 \mathrm{~nm}$ was measured in triplicate using an enzyme-linked immunosorbent assay reader (Dynex Mrx II, Chantilly, VA, USA). Respiratory burst was expressed as NBT reduction $100 \mathrm{\mu l}^{-1}$ of hemolymph.

Statistical analysis. A multiple comparison (Tukey) test was conducted to compare the significant difference among treatments using the SAS computer software (SAS Institute Inc., Cary, NC, USA). For statistically significant differences, it was required that $\mathrm{p}<0.05$.

\section{RESULTS}

\section{Effect of copper sulfate in the growth medium on the} growth of Lactococcus garvieae

Lactococcus garvieae grew well in the TSB medium containing copper sulfate even at $0.4 \mathrm{mg} \mathrm{l}^{-1}$. The log phase occurred at 12 to $24 \mathrm{~h}$, and the bacterial density after $24 \mathrm{~h}$ of incubation was the highest in all test media.

\section{Effect of copper sulfate on the virulence of Lactococcus garvieae}

All the unchallenged control prawns survived. In contrast, in the challenged prawns deaths began to occur at $16 \mathrm{~h}$. The cumulative mortality of prawns after $48 \mathrm{~h}$ was significantly higher for prawns challenged by the bacteria incubated in TSB medium containing $0.4 \mathrm{mg} \mathrm{l}^{-1}$ copper sulfate than for those challenged by bacteria at other concentrations (Table 1).

\section{Effect of copper sulfate in the holding water on the resistance of Macrobrachium rosenbergii to Lactococcus garvieae}

All the unchallenged control prawns survived. At a challenge dose of $4 \times 10^{6} \mathrm{cfu}_{\text {prawn }}{ }^{-1}$, onset of mortality occurred earlier at $0.2,0.3$ and $0.4 \mathrm{mg} \mathrm{l}^{-1}$ copper sulfate $(8 \mathrm{~h})$ than among prawns at $0.1 \mathrm{mg} \mathrm{l}^{-1}$ copper sulfate $(24 \mathrm{~h})$. After $24 \mathrm{~h}$, cumulative mortality of prawns was significantly higher in $0.4 \mathrm{mg} \mathrm{l}^{-1}$ than at other concentrations. Cumulative mortality over $96 \mathrm{~h}$ was $26.7,20.0,36.7,30.0$ and $50.0 \%$ for the prawns placed in $0,0.1,0.2,0.3$ and $0.4 \mathrm{mg} \mathrm{l}^{-1}$ copper sulfate, respectively (Table 2 ). Reducing the challenge dose to $2 \times 10^{5}$ cfu prawn $^{-1}$ delayed the onset of mortality (16 h for the $0.3 \mathrm{mg} \mathrm{l}^{-1}$ group and $72 \mathrm{~h}$ for the $0.2 \mathrm{mg} \mathrm{l}^{-1}$ group). After $72 \mathrm{~h}$, cumulative mortality of prawns increased directly with ambient copper sulfate in the range from 0.2 to $0.4 \mathrm{mg} \mathrm{l}^{-1}$. Cumulative mortality over the $96 \mathrm{~h}$ period was $10.0,23.3$ and $40.0 \%$ in $0.2,0.3$ and $0.4 \mathrm{mg} \mathrm{l}^{-1}$ copper sulfate, respectively. However, all prawns survived in $0.1 \mathrm{mg} \mathrm{l}^{-1}$ copper sulfate over $96 \mathrm{~h}$ (Table 2). 
Table 3. Effect of different concentrations of copper sulfate on hyaline cells (HC), granular cells (GC), semi-granular cells (SGC) and total hemocyte count (THC). Data in the same category with the same letter are not significantly different ( $p>0.05)$. Values are means $\pm \mathrm{SE}$

\begin{tabular}{|lccccccc|}
\hline Hemocyte & $\begin{array}{c}\text { Sampling } \\
\text { time (h) }\end{array}$ & $\begin{array}{c}\text { No. } \\
\text { prawns }\end{array}$ & Control & 0.1 & $\mathrm{CuSO}_{4}\left(\mathrm{mg} \mathrm{l}^{-1}\right)$ & 0.2 & 0.3 \\
\hline $\mathrm{HC}\left(\times 10^{5} \mathrm{ml}^{-1}\right)$ & 0 & 6 & $65.58 \pm 9.17^{\mathrm{a}}$ & $72.22 \pm 11.80^{\mathrm{a}}$ & $76.55 \pm 27.16^{\mathrm{a}}$ & $82.15 \pm 16.70^{\mathrm{a}}$ & $77.08 \pm 15.44^{\mathrm{a}}$ \\
& 96 & 6 & $107.28 \pm 25.45^{\mathrm{a}}$ & $75.77 \pm 9.00^{\mathrm{a}}$ & $85.72 \pm 9.77^{\mathrm{a}}$ & $78.58 \pm 17.41^{\mathrm{a}}$ & $76.95 \pm 13.24 \mathrm{a}$ \\
$\mathrm{GC}\left(\times 10^{5} \mathrm{ml}^{-1}\right)$ & 0 & 6 & $3.75 \pm 0.72^{\mathrm{a}}$ & $3.95 \pm 1.33^{\mathrm{a}}$ & $4.59 \pm 0.80^{\mathrm{a}}$ & $4.03 \pm 1.40^{\mathrm{a}}$ & $3.88 \pm 0.51^{\mathrm{a}}$ \\
& 96 & 6 & $3.10 \pm 0.63^{\mathrm{a}}$ & $4.07 \pm 1.28^{\mathrm{a}}$ & $4.10 \pm 1.23^{\mathrm{a}}$ & $3.66 \pm 1.31^{\mathrm{a}}$ & $3.05 \pm 1.08^{\mathrm{a}}$ \\
$\mathrm{SGC}\left(\times 10^{5} \mathrm{ml}^{-1}\right)$ & 0 & 6 & $4.31 \pm 2.10^{\mathrm{a}}$ & $3.54 \pm 0.71^{\mathrm{a}}$ & $4.18 \pm 1.35^{\mathrm{a}}$ & $3.70 \pm 1.39^{\mathrm{a}}$ & $4.02 \pm 0.46^{\mathrm{a}}$ \\
& 96 & 6 & $3.30 \pm 0.60^{\mathrm{a}}$ & $3.52 \pm 1.33^{\mathrm{a}}$ & $4.02 \pm 1.28^{\mathrm{a}}$ & $3.73 \pm 0.42^{\mathrm{a}}$ & $3.47 \pm 1.12^{\mathrm{a}}$ \\
$\mathrm{THC}\left(\times 10^{5} \mathrm{ml}^{-1}\right)$ & 0 & 6 & $73.64 \pm 6.81^{\mathrm{a}}$ & $79.71 \pm 12.68^{\mathrm{a}}$ & $85.32 \pm 29.39^{\mathrm{a}}$ & $89.88 \pm 17.78^{\mathrm{a}}$ & $81.10 \pm 15.47^{\mathrm{a}}$ \\
& 96 & 6 & $113.68 \pm 24.35^{\mathrm{a}}$ & $83.35 \pm 9.48^{\mathrm{a}}$ & $93.83 \pm 11.47^{\mathrm{a}}$ & $89.33 \pm 19.81^{\mathrm{a}}$ & $83.47 \pm 14.69^{\mathrm{a}}$ \\
& & & & & & &
\end{tabular}

\section{Effect of copper sulfate on the immune parameters of Macrobrachium rosenbergii}

No significant differences in THC and DHC were observed among the prawns at the beginning of the tests and at 48 and $96 \mathrm{~h}$. The hyaline cells constituted 88 to $95 \%$ of the hemocytes, and varied from $65.6 \pm$ $9.2 \times 10^{5}$ (mean $\pm \mathrm{SE}$ ) to $107.3 \pm 25.5 \times 10^{5} \mathrm{cells} \mathrm{m}^{-1}$. The mean $( \pm \mathrm{SE})$ of THC varied from $73.6 \pm 6.8 \times 10^{5}$ to $113.7 \pm 24.4 \times 10^{5}$ cell ml $^{-1}$ for THC (Table 3 ).

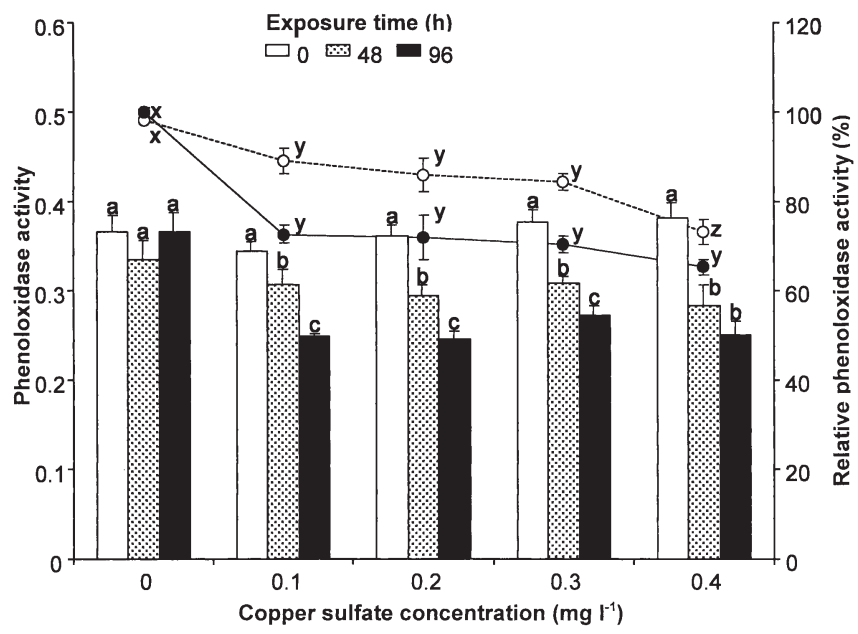

Fig. 1. Mean $( \pm \mathrm{SE})$ phenoloxidase activity in the hemocytes of Macrobrachium rosenbergii at 0,48 and $96 \mathrm{~h}$ exposure to copper sulfate, and relative phenoloxidase activity (compared with the activity at $0 \mathrm{~h}$ ) of prawns exposed to different concentrations of copper sulfate. Each bar represents the mean value from 6 determinations with standard error. Data of phenoloxidase activity (in column) in the same copper sulfate concentration having different letters of $\mathrm{a}, \mathrm{b}$ and $\mathrm{c}$ are significantly different $(p<0.05)$ among the prawns at 0,48 and $96 \mathrm{~h}$. Data of relative phenoloxidase activity (in dotted line and solid line) having different letters of $\mathrm{x}, \mathrm{y}$ and $\mathrm{z}$ are significantly different $(\mathrm{p}<0.05)$ among different copper sulfate concentrations after 48 and $96 \mathrm{~h}$, respectively
No significant difference in phenoloxidase activity was observed among prawns placed in the control solution at 0, 48 and $96 \mathrm{~h}$. Phenoloxidase activity decreased with exposure time at all copper concentrations. After $48 \mathrm{~h}$, the relative phenoloxidase activity (compared with the activity at $0 \mathrm{~h}$ ) at $0.1,0.2,0.3$ and $0.4 \mathrm{mg} \mathrm{l}^{-1}$ copper sulfate was $89.1,86.0,84.4$ and $73.2 \%$, respectively. After $96 \mathrm{~h}$, the relative phenoloxidase activity at $0.1,0.2,0.3$ and $0.4 \mathrm{mg} \mathrm{l}^{-1}$ copper sulfate was $72.7,71.8$, 70.3 and $65.2 \%$, respectively (Fig. 1).

No significant difference in respiratory burst was observed among the prawns placed in the control solution at 0,48 and $96 \mathrm{~h}$. Respiratory burst in prawns following $48 \mathrm{~h}$ exposure to copper sulfate was significantly higher than at $0 \mathrm{~h}$. After $48 \mathrm{~h}$, the relative respiratory burst (compared with the activity at $0 \mathrm{~h}$ ) increased directly with copper sulfate in the range of 0.1 to $0.3 \mathrm{mg} \mathrm{l}^{-1}$. The relative respiratory burst of prawns placed in $0.1,0.2,0.3$ and $0.4 \mathrm{mg} \mathrm{l}^{-1}$ copper sulfate was $112.7,156.1,166.4$ and $146.1 \%$, respectively. After $96 \mathrm{~h}$, the relative respiratory burst at $0.1,0.2,0.3$ and $0.4 \mathrm{mg} \mathrm{l}^{-1}$ copper sulfate was 104.4, 112.6, 154.9 and $132.2 \%$, respectively (Fig. 2).

\section{DISCUSSION}

Weinberg (1985) reported that media containing iron and manganese affected the growth of pathogen, and modulated the yields of bacterial enzymes and toxins. For example, in complex medium, the optimal iron concentration for maximal production of the neurotoxins of Clostridium botulinum was 5.4 $\mu \mathrm{M}$ (Siegel 1981). Cheng \& Chen (1999) reported that Lactococcus garvieae incubated in brain heart infusion broths at $\mathrm{pH}$ 7 to 8 and temperature of 25 to $30^{\circ} \mathrm{C}$ resulted in significantly enhanced virulence to Macrobrachium rosenbergii. In our study, the fact that mortality was higher for $M$. rosenbergii challenged with L. garvieae previ- 


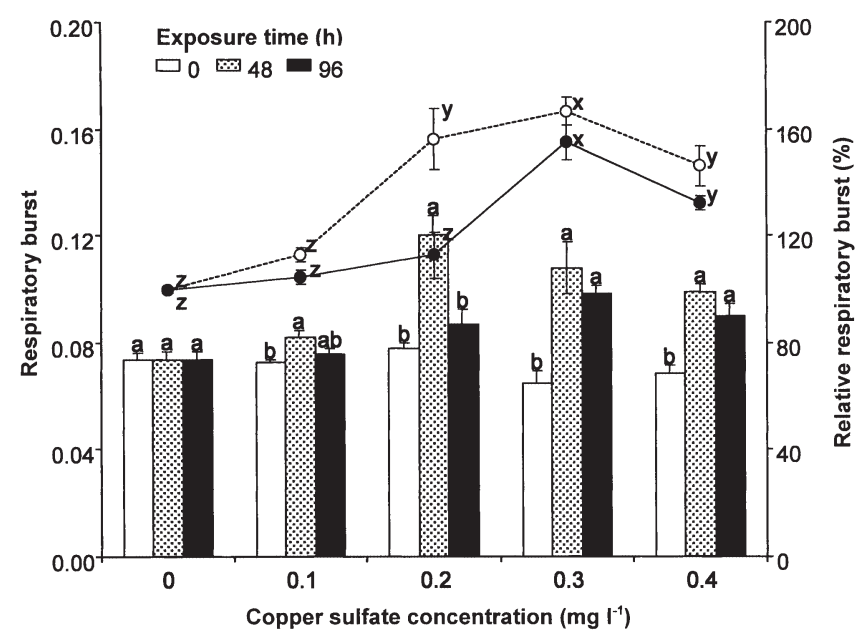

Fig. 2. Mean $( \pm \mathrm{SE})$ respiratory burst in the hemocytes of Macrobrachium rosenbergii at 0,48 and $96 \mathrm{~h}$ exposure to copper sulfate, and relative respiratory burst (compared with the activity at $0 \mathrm{~h}$ ) of prawns exposed to different concentrations of copper sulfate. See Fig. 1 for statistical information

ously incubated in TSB medium with $0.4 \mathrm{mg} \mathrm{l}^{-1}$ copper sulfate indicates that copper sulfate enhanced the virulence of $L$. garvieae to $M$. rosenbergii.

Our previous research indicated that Macrobrachium rosenbergii were most susceptible to Lactococcus garvieae when they were reared at $\mathrm{pH} 8.8$ to 9.5 and temperatures of 33 to $34^{\circ} \mathrm{C}$ (Cheng \& Chen 1998b). In the present study, M. rosenbergii were most susceptible to $L$. garvieae when reared in water containing copper sulfate at $0.4 \mathrm{mg} \mathrm{l}^{-1}$, as compared to those exposed to 0.2 and $0.3 \mathrm{mg} \mathrm{l}^{-1}$ copper sulfate. However, the fact that $M$. rosenbergii challenged with $2 \times 10^{5}$ cfu prawn $^{-1}$ and placed in $0.1 \mathrm{mg} \mathrm{l}^{-1}$ copper sulfate survived $96 \mathrm{~h}$ suggests an increase in resistance. In conclusion, the susceptibility of $M$. rosenbergii to $L$. garvieae is greatly affected by high $\mathrm{pH}$ level, high temperature and the presence of copper sulfate in water.

In decapod crustaceans, the number of hemocytes that are associated with cellular defense varies with species (Hose et al. 1990). Effects of intrinsic factors such as season, sex, size and body weight on the THC of Macrobrachium rosenbergii have been studied (Cheng \& Chen 2001). M. rosenbergii displayed the highest and lowest THC in autumn and winter, respectively. There was no significant difference between male and female prawns or among animals with body weights ranging from 7 to 115 g. M. rosenbergii displayed the lowest THC at the $\mathrm{D}_{3}$ stage and the highest at $C$ stage (Cheng \& Chen 2001). In the present study, the $M$. rosenbergii used were at the $\mathrm{C}$ stage and were therefore considered to be similar with regard to defense.
Extrinsic factors such as temperature, salinity and dissolved oxygen have been reported to affect THC in several species of decapod crustaceans (Truscott \& White 1990, Le Moullac et al. 1998, Le Moullac \& Haffner 2000, Cheng \& Chen 2001). In the blue shrimp Penaeus stylirostris exposed to low temperature $\left(18^{\circ} \mathrm{C}\right)$, a significant drop in THC $(40 \%)$ was observed compared to that for prawns at $27^{\circ} \mathrm{C}$ (Le Moullac \& Haffner 2000). An increase of temperature from 10 to $20^{\circ} \mathrm{C}$ and from 18 to $32^{\circ} \mathrm{C}$ has been reported to increase THC of Carcinus maenas and Penaeus californensis, respectively (Truscott \& White 1990, VargasAlbores et al. 1998). Brazilian shrimp Penaeus paulensis, reared at $34 \%$ had a significantly higher THC (20\% more) than shrimp reared at 22 and $13 \%$ (Le Moullac \& Haffner 2000). Decreased THC in $P$. stylirostris was observed following $24 \mathrm{~h}$ exposure to dissolved oxygen as low as $1 \mathrm{mg} \mathrm{l}^{-1}$ (Le Moullac et al. 1998). These studies indicated that the decrease of THC was due mainly to the decrease of hyaline cells.

In addition to physico-chemical parameters, environmental pollutants such as heavy metals have been reported to affect THC in several species of invertebrates. Cheng (1988) reported that Eastern oyster Crassostrea virginica, after 3 to $14 \mathrm{~d}$ of exposure to $1 \mathrm{mg} \mathrm{l}^{-1} \mathrm{Cd}^{2+}$, showed increased $\mathrm{THC}$, and indicated that the increase was due to an increase in number of hyaline cells. The freshwater prawn Macrobrachium idea following $30 \mathrm{~d}$ exposure to $1 \mathrm{\mu g}^{-1}$ mercuric chloride exhibited hyperplastic gill lamella engorged with hemocytes (Victor et al. 1990). Truscott \& White (1990) reported that no significant change in hemocyte count was observed in Carcinus maenas following $30 \mathrm{~d}$ exposure to $50 \mathrm{\mu g} \mathrm{l}^{-1} \mathrm{Hg}^{2+}$. Penaeus stylirostris following exposure to ammonia at 1.5 and $3.0 \mathrm{mg} \mathrm{l}^{-1}$ showed decreased THC by 15 and $50 \%$, and decreased phenoloxidase activity by 60 and $50 \%$, respectively (Le Moullac \& Haffner 2000). In the present study, no significant difference in THC and DHC was observed among the prawns exposed to copper sulfate in the range of 0 to $0.4 \mathrm{mg} \mathrm{l}^{-1}$.

Generation of various reactive oxygen intermediates from hemocytes responding to invasive pathogens or foreign particles has been observed in several species of mollusks (Adema et al. 1991, Pipe 1992, Anderson 1994). The hemocytes from Crassostrea virginica heavily infected with protozoan parasites produced significantly higher levels of reactive oxygen intermediates than hemocyte withdrawn from lightly infected oysters (Anderson 1994). NBT staining in Penaeus stylirostris following exposure to low concentrations of dissolved oxygen $\left(1 \mathrm{mg} \mathrm{l}^{-1}\right)$ was decreased (Le Moullac et al. 1998) but the activity of NADPH oxidase, which produces superoxide anion from molecular oxygen, was not affected under hypoxia. In white shrimp Penaeus 
vannamei, following injection of the fungicide propiconazol, the respiratory burst increased at Day 6 but decreased at Day 13 (Le Moullac \& Haffner 2000). Elevated superoxide concentrations in Drosophila during melanotic encapsulation of parasites has been observed (Nappi et al. 1995). In an in vitro experiment using Carcinus maenas, superoxide anion production has been reported in hyaline cells (Bell \& Smith 1993).

Pipe et al. (1999) indicated that the release of reactive oxygen intermediates from hemocytes increased directly with ambient copper but decreased significantly when the concentration was $0.5 \mathrm{mg} \mathrm{l}^{-1}$. They suggested that a threshold of copper between 0.2 and $0.5 \mathrm{mg} \mathrm{l}^{-1}$ inhibited the production of reactive oxygen intermediates. In this study, the phenoloxidase activity of Macrobrachium rosenbergii decreased but the respiratory burst increased at $0.1 \mathrm{mg} \mathrm{l}^{-1}$ copper sulfate. A challenge test at a low dose also indicated that $M$. rosenbergii survived for $96 \mathrm{~h}$ at $0.1 \mathrm{mg} \mathrm{l}^{-1}$ copper sulfate. These findings may suggest that the NADPH oxidase is activated to produce superoxide anion under the stress of copper sulfate. The observation that in $M$. rosenbergii following $48 \mathrm{~h}$ exposure to $0.2 \mathrm{mg} \mathrm{l}^{-1}$ or more copper sulfate superoxide anion increased significantly but also phenoloxidase activity decreased significantly suggests that copper sulfate promoted cytoxicity and acted as an immunodepressor in M. rosenbergii.

It is known that copper induces immunomodulation in the marine mussel Mytilus edulis (Pipe \& Coles 1995, Pipe et al. 1999) and increases the susceptibility to Vibrio tubiashi infection (Pipe \& Coles 1995). Cheng \& Chen (1998b) reported that the impact of Lactococcus garvieae on Macrobrachium rosenbergii was exacerbated by high $\mathrm{pH}$ (8.8 to 9.5) and high temperature (33 to $34^{\circ} \mathrm{C}$ ) but was reduced by low salinity ( 5 to $10 \%$ ) indicating enhanced susceptibility of $M$. rosenbergii to L. garvieae. Copper sulfate increased respiratory burst but decreased phenoloxidase activity in $M$. rosenbergii, suggesting a possible reason for increased susceptibility to $L$. garvieae and indicating that copper sulfate might work as an immunomodulator in $M$. rosenbergii.

In conclusion, the immune system of Macrobrachium rosenbergii is modulated by copper sulfate. There is an increased virulence of Lactococcus garvieae to $M$. rosenbergii when it is first exposed to copper sulfate, and the susceptibility of $M$. rosenbergii to L. garvieae is enhanced by the stress of copper sulfate.

Acknowledgements. This research was supported by the Council of Agriculture (89-Ke-Chi-1.2-Yu-04-29) and National Science Council (NSC 90-2313-B-020-019) of the Republic of China. We thank Dr S. C. Sheu, Associate Professor of the Department of Food Science in our university, for the use of the ELISA reader, and Messrs C.-H. Liu and C.-H. Chang for assistance in the experiment.

\section{LITERATURE CITED}

Adema CM, van der Knapp WPM, Sminia T (1991) Molluscan haemocyte-mediated cytotoxicity: the role of reactive oxygen intermediates. Rev Aquat Sci 4:210-223

Anderson RS (1994) Hemocyte-derived reactive oxygen intermediate production in four bivalve mollusks. Dev Comp Immunol 18:89-96

Bachère E, Miahle E, Rodriguez J (1995) Identification of defence effectors in the haemolymph of crustaceans with particular reference to the shrimp Penaeus japonicus (Bate): prospects and application. Fish Shellfish Immunol 5:597-612

Bell KL, Smith VJ (1993) In vitro superoxide production by hyaline cells of the shore crab Carcinus maenas (L.). Dev Comp Immunol 17:211-219

Boyd CE (1990) Water quality in ponds for aquaculture. Birmingham Publishing Co., Birmingham

Chen SC, Lin YD, Liaw LL, Wang PC (2001) Lactococcus garvieae infection in the giant freshwater prawn Macrobrachium rosenbergii confirmed by polymerase chain reaction and 16s rDNA sequencing. Dis Aquat Org 45: $45-52$

Cheng TC (1988) In vivo effects of heavy metals on cellular defense mechanisms of Crassostrea virginica: total and differential cell counts. J Invertebr Pathol 51:207-214

Cheng W, Chen JC (1998a) Isolation and characterization of Enterococcus-like bacterium causing muscle necrosis and mortality with Macrobrachium rosenbergii in Taiwan. Dis Aquat Org 34:93-101

Cheng W, Chen JC (1998b) Enterococcus-like infections Macrobrachium rosenbergii are exacerbated by high $\mathrm{pH}$ and temperature but reduced by low salinity. Dis Aquat Org 34:103-108

Cheng W, Chen JC (1999) Effect of cultivation broth pH, temperature and $\mathrm{NaCl}$ concentration on virulence of an Enterococcus-like bacterium to the giant freshwater prawn Macrobrachium rosenbergii. Dis Aquat Org 36:233-237

Cheng W, Chen JC (2000) Effects of pH, temperature and salinity on immune parameters of the freshwater prawn Macrobrachium rosenbergii. Fish Shellfish Immunol 10: 387-391

Cheng W, Chen JC (2001) Effect of intrinsic and extrinsic factors on the haemocyte profile of the prawn, Macrobarchium rosenbergii. Fish Shellfish Immunol 11:53-63

Herãndez-López J, Gollas-Galván TS, Vargas-Albores F (1996) Activation of the prophenoloxidase system of the brown shrimp (Penaeus californiensis Holmes). Comp Biochem Physiol 113C:61-66

Holmblad T, Söderhäll K (1999) Cell adhesion molecules and antioxidative enzymes in a crustacean, possible role in immunity. Aquaculture 172:111-123

Hose JE, Martin GG, Gerard AS (1990) A decapod hemocyte classification scheme integrating morphology, cytochemistry, and function. Biol Bull 178:33-45

Ismail P, Mohamad MN, Cheah SH (1990) Toxicity of copper to larval and postlarval stages of Macrobrachium rosenbergii (De Man). In: Hirano R, Hanyu I (eds) The second Asian Fisheries Forum. The Asian Fisheries Society, Manila, p 927-930

Johansson MW, Söderhäll K (1989) Cellular immunity in crustaceans and the proPO system. Parasitol Today 5:171-176

Le Moullac G, Haffner P (2000) Environmental factors affecting immune response in crustacea. Aquaculture 191: 121-131

Le Moullac G, Soyez C, Saulnier D, Ansquer D, Avarre JC, Levy P (1998) Effect of hypoxia stress on the immune 
response and the resistance to vibriosis of the shrimp Penaeus stylirostris. Fish Shellfish Immunol 8:621-629

Nappi AJ, Vass E, Frey F, Carton Y (1995) Superoxide generation in Drosophila during melanotic encapsulation of parasites. Eur J Cell Biol 68:450-456

New MB (1995) Status of freshwater prawn farming: a review. Aquacult Res 26:1-54

Pipe RK (1992) Generation of reactive oxygen metabolites by the haemocytes of the mussel, Mytilus edulis. Dev Comp Immunol 16:111-122

Pipe RK, Coles JA (1995) Environmental contaminants influencing immune function in marine bivalve molluscs. Fish Shellfish Immunol 5:581-595

Pipe RK, Coles JA, Carissan FMM, Ramanathan K (1999) Copper induced immunomodulation in the marine mussel, Mytilus edulis. Aquat Toxicol 46:43-54

Roch P (1999) Defense mechanisms and disease prevention in farmed marine invertebrates. Aquaculture 172:125-145

Siegel LS (1981) Effect of iron on growth and toxin production by Clostridium botulinum Type A. Curr Microbiol 6: 127

Smith VJ, Johnston PA (1992) Differential haemotoxic effect of PCB congeners in the common shrimp, Crangon crangon. Comp Biochem Physiol 101C:641-649

Smith VJ, Söderhäll K, Hamilton M (1984) $\beta$-1.3-glucan induced cellular defense reaction in the shore crab, Carcinus maenas. Comp Biochem Physiol 77A:636-639

Smith VJ, Swindlehurst RJ, Johnston PA, Vethaak AD (1995) Distribution of host defence capability in the common shrimp, Crangon crangon, by exposure to harbour dredge spoils. Aquat Toxicol 32:43-58

Editorial responsibility: Timothy Flegel, Bangkok, Thailand
Söderhäll K (1983) $\beta$-1.3-glucan enhancement of protease activity in crayfish hemocyte lysate. Comp Biochem Physiol 74B:221-224

Söderhäll K, Cerenius L, Johansson MW (1996) The prophenoloxidase activating system in invertebrates. In: Söderhäll K, Iwanaga SGR, Vasta GR (eds) New directions in invertebrate immunology. SOS Publications, Fair Haven, p 229-253

Song YL, Hsieh YT (1994) Immunostimulation of tiger shrimp (Penaeus monodon) hemocytes for generation of microbicidal substances: analysis of reactive oxygen species. Dev Comp Immunol 18:201-209

Suresh K, Mohandas A (1990) Effect of sublethal concentrations of copper on hemocyte number in bivalves. J Invertebr Pathol 55:325-331

Truscott R, White KN (1990) The influence of metal and temperature stress on the immune system of crabs. Funct Ecol $4: 455-461$

Tsing A, Arcier JM, Brèhèlin M (1989) Haemocytes of penaeids and palaemonid shrimps: morphology, cytochemistry and hemograms. J Invertebr Pathol 53:64-77

Vargas-Albores F, Baltazar PH, Clark GP, Barajas FM (1998) Influence of temperature and salinity on the yellowlegs shrimp, Penaeus californiensis Holmes, prophenoloxidase system. Aquat Res 29:549-553

Victor B, Narayanan M, Nelson D (1990) Gill pathology and hemocyte response in mercury exposed Macrobrachium idea (Heller). J Environ Biol 11:61-65

Weinberg ED (1985) Enzymes, nutrition, and virulence. In: Holder IA (ed) Bacterial enzymes and virulence. CRC Press, Boca Raton, FL, p 1-16

Submitted: August 16, 2000; Accepted: March 13, 2001

Proofs received from author(s): October 24, 2001 